\title{
Data Delivery and Mapping Over the Web National Water-Quality Assessment Data Warehouse
}

By Richard W. Bell and Alex K. Williamson

The U.S. Geological Survey (USGS) began its National Water-Quality Assessment (NAWQA) Program in 1991, systematically collecting chemical, biological, and physical waterquality data from study units (basins) across the Nation. In 1999, the NAWQA Program developed a data warehouse (fig. 1) to better facilitate national and regional analysis of data from 36 study units started in 1991 and 1994. Data from 15 study units started in 1997 were added to the warehouse in 2001. The warehouse currently contains and links the following data:

- Chemical concentrations in water, sediment, and aquatic-organism tissues and related quality-control data from the USGS National Water Information System (NWIS),

- Biological data for stream-habitat and ecologicalcommunity data on fish, algae, and benthic invertebrates,

- Site, well, and basin information associated with thousands of descriptive variables derived from spatial analysis, like land use, soil, and population density, and

- Daily streamflow and temperature information from NWIS for selected sampling sites.

The warehouse contains data for about 2,000 water-quality and biological constituents or properties analyzed in samples

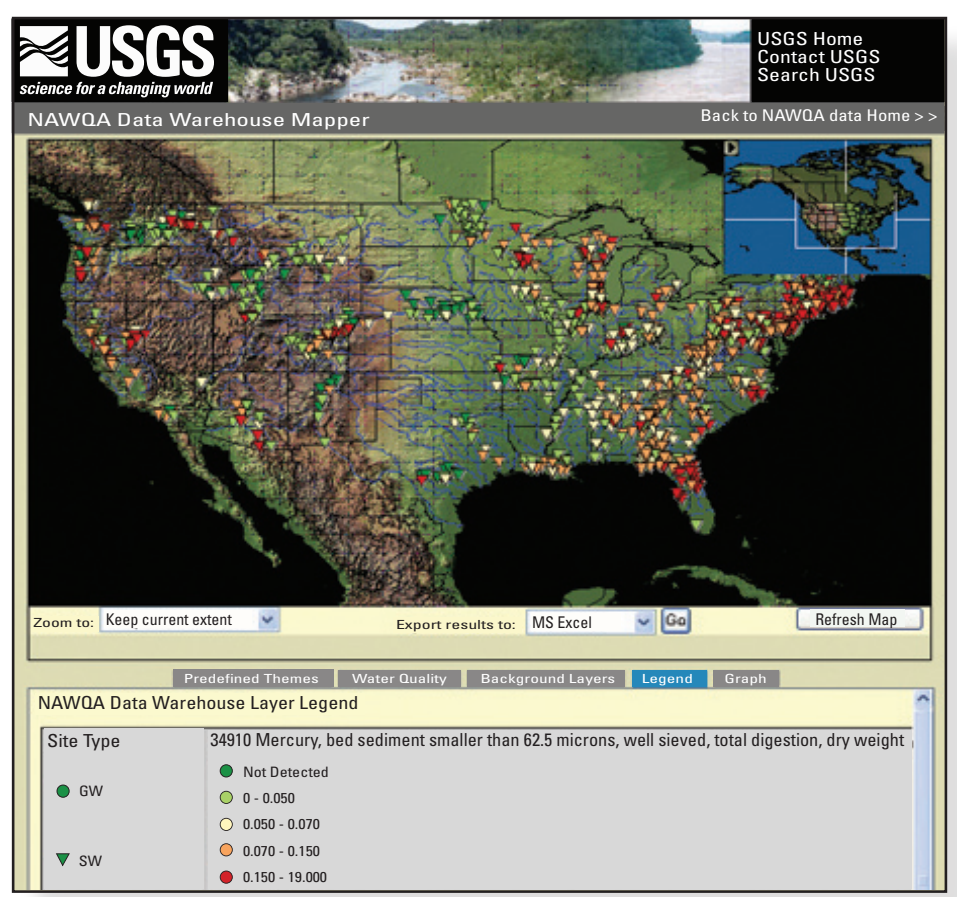

Figure 2. Mapping interface example-mercury in streambed sediment.

collected at about 7,600 surface-water sites and 8,100 wells selected to be representative of various land uses. About 48,000 nutrient samples, 30,000 pesticide samples, and 8,100 volatile organic compound samples were collected from the water column. About 2,600 samples from streambed sediment and animal tissue were collected and analyzed for hydrophobic compounds. Most water, sediment, and tissue samples were analyzed for more than 40 different compounds. The biological and ecological data listed above were collected at many of the same stream sites. Collectively, these data represent about 14 million records in the data warehouse.

Data for environmental samples of water, sediment, and tissue, as well as the site and well information and daily streamflow and temperature data, were made available in 2000 through the data warehouse home page (fig. 1). An example of a popular retrieval option (using the "MAP SITES \& RESULTS" application) showing locations of NAWQA Program sites and concentrations of selected chemicals is shown in figure 2. Most NAWQA data are available through the public version of the data warehouse-exceptions include the most recent water year's data, some biological data, and some site-, basin-, and well-descriptive variables and quality-control data that are available by request from individual study units.

Figure 1. Data warehouse home page (http://water.usgs.gov/nawqa/data). 


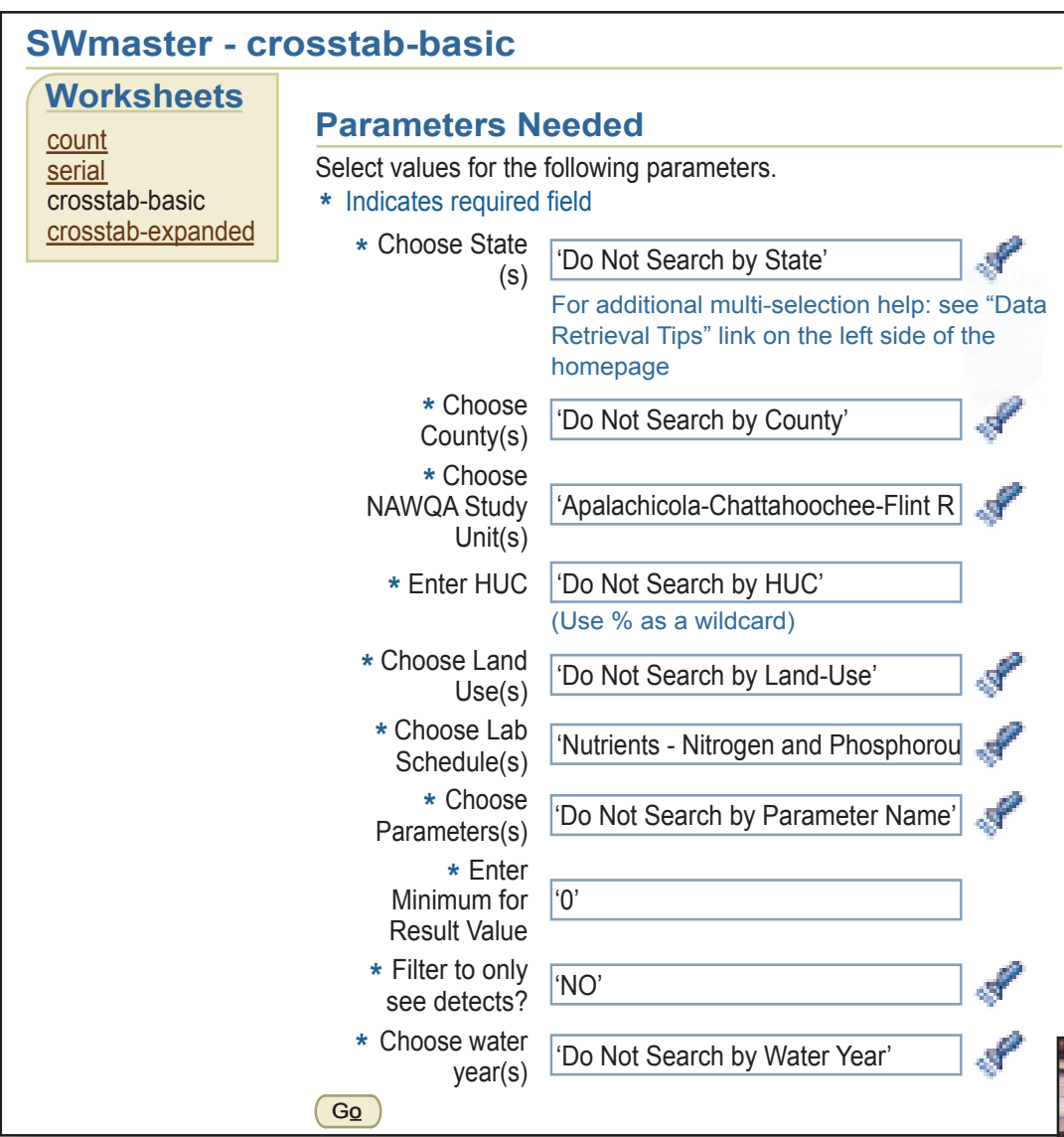

Figure 3. Example of the search-criteria interface retrieval option.

\section{Data Warehouse Interface}

The NAWQA data warehouse home page includes a variety of options for retrieving data collected at NAWQA Program sites, generating location maps and summary graphics, information about program background and design, and guidance pages and tutorials for navigating through the data warehouse pages and using the applications. Information contained in the data warehouse is accessed using a series of selection windows. To retrieve a dataset from the data warehouse and copy the resulting table to a local computer, users select from the "RETRIEVE DATA" section (fig. 1, left frame): the desired medium type, for example Ground Water, Surface Water/Bed Sediment, Mixed, Animal Tissue, Daily Stream Discharge, or Bio Community. A new viewer window appears that allows the user to choose output options; after selecting a type of output (such as "Serial (Long) Output"), users select their search criteria, such as State, study-unit, land-use, laboratory schedule or parameter information (fig. 3). Additional selection criteria are available depending on the type of retrieval. After the retrieval is completed, users select an export-file format.

Results of data retrievals (fig. 4) can be displayed in a variety of table formats depending on the needs and choices of the user. Data tables can be exported and saved locally in a variety of popular formats, including Excel, tab-delimited, and HTML.

Government officials, consultants, researchers, and the public retrieve data from the NAWOA Data Warehouse.

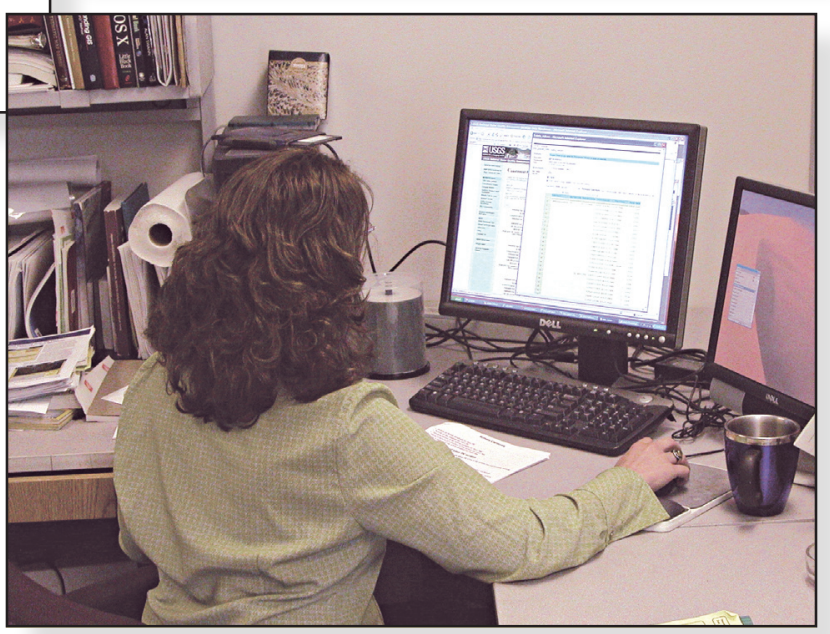

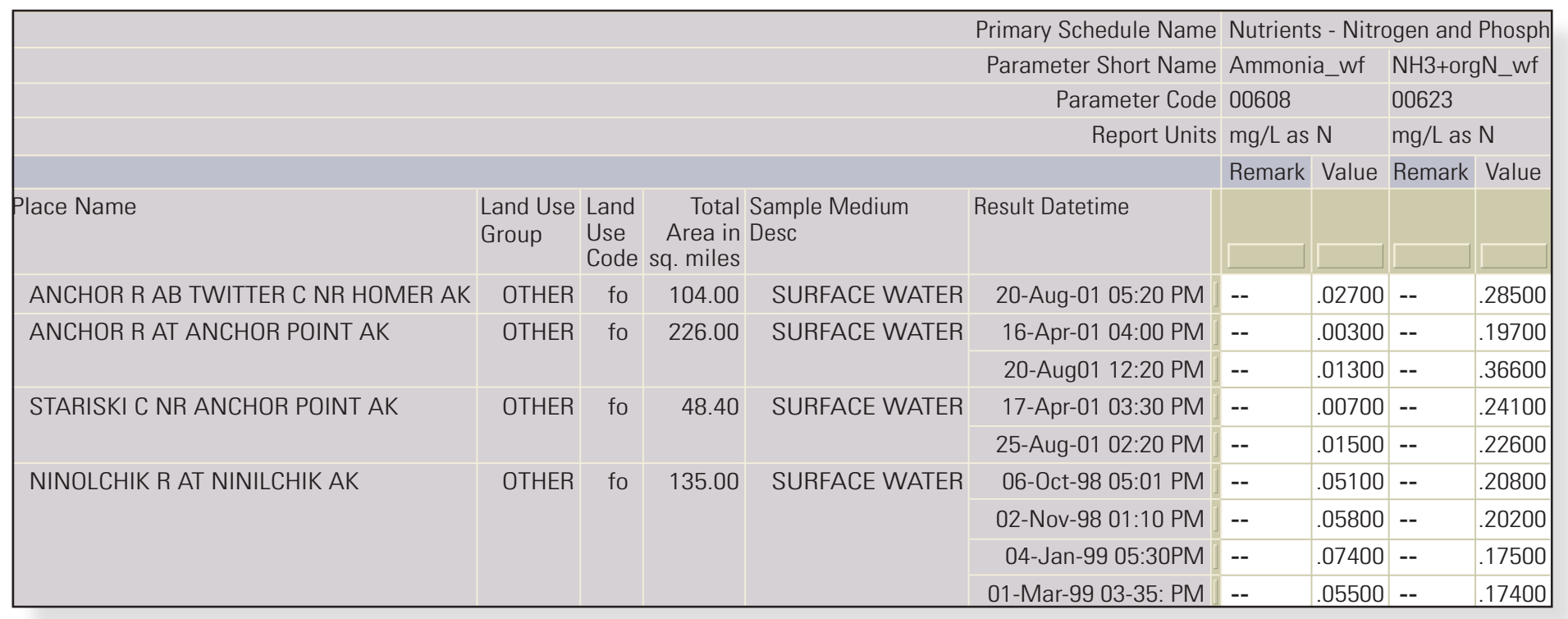

Figure 4. Example of output using the surface water cross-tabulation retrieval option. 


\section{Mapping Concentrations of Chemicals Using Only Your Web Browser}

Users can create maps showing the location of sampling sites and concentrations of chemical compounds at the sampling sites (fig. 5). The maps can be modified by the user to show results from NAWQA study units throughout the United
States (fig. 2) or the display can be "zoomed in" to focus on specific areas of interest (fig. 5). In addition to modifying the view of sampling sites, users also can select chemical compounds of interest, type of site, groupings of sites by State, USEPA region, and NAWQA study unit (basin), and specify "break points" to modify the range of concentrations that are displayed. Also, individual sampling sites on the map can be selected to show the site name, site identification number, different site characteristics, and results of all the analyses.

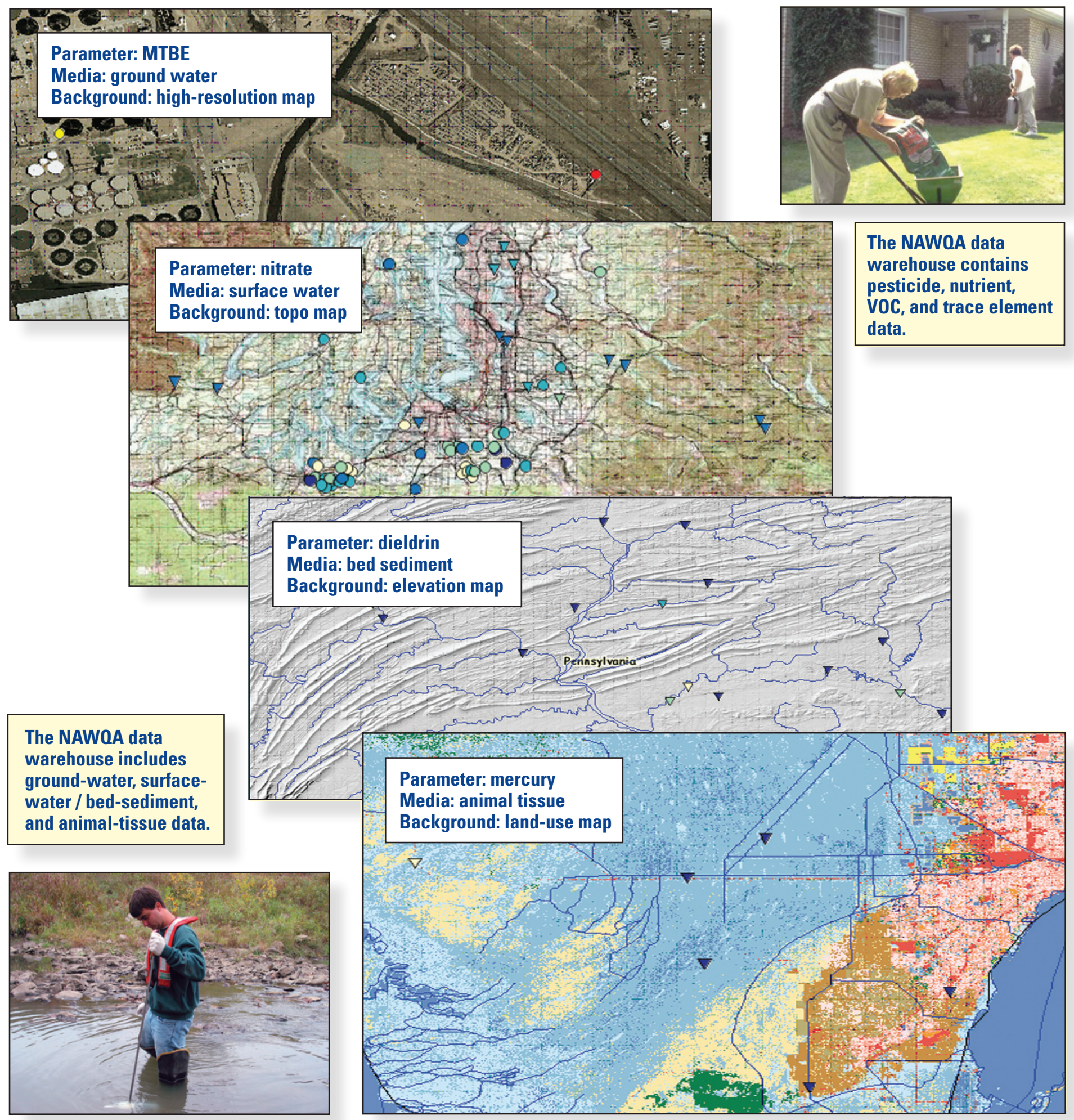

Figure 5. Maps showing location of sites where a chemical compound (parameter) was detected, with concentration indicated by color of site symbols. 


\section{Biological Information}

Biological community samples (fish, benthic invertebrates, algae) are collected in streams and rivers as part of ecological studies in the NAWQA Program. During the Program's first decade of operation (1991-2001), studies were conducted to assess the occurrence and distribution of fish, invertebrate, and algal communities.

The retrievals for fish, invertebrate, and algal communities include sample count, taxonomic list, and sample abundance (fig. 6). The retrieval process for biological-community samples is similar to the process described in the "Data Warehouse Interface" section. Note the link to ITIS (Integrated Taxonomic Information System) reports.

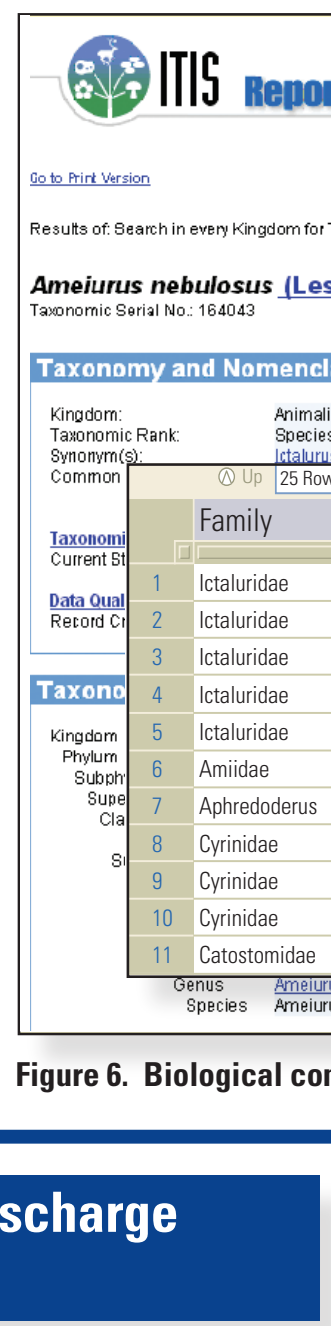

Users can retrieve stream discharge (mean daily values) for NAWQA sites equipped with instruments to monitor streamflow (fig. 7).

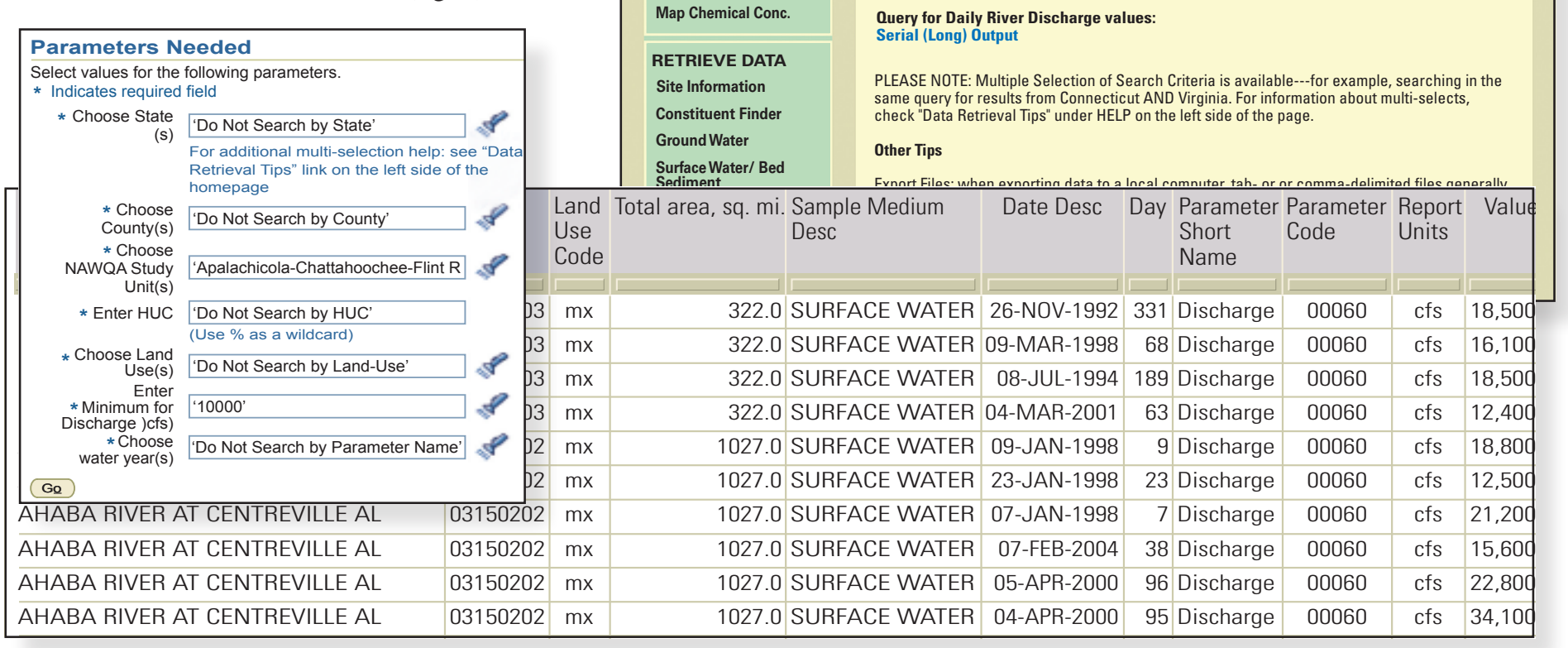

Figure 7. Examples of output table using the daily discharge option.

NAWOA Data Home

MAP SITES \&

RESULTS

Map Chemical Conc. Select a data reterival option:

\begin{tabular}{ll}
\hline RETRIEVE DATA & Sample Count \\
Taxonomic List Fish
\end{tabular}

Taxonomic List Invert

\begin{tabular}{l|l} 
Constituent Finder & Sample Abundance Fish \\
\hline
\end{tabular}

Sample Abundance Invert

Sample Abundance Algae Periphyton

Sample Abundance Algae Phytoplankton

Surface Water/ Bed

Mixed (SW \& GW)

Animal Tissue

Daily Stream Discharge

Bological community samples (fish, invertebrates, algae) are collected in streams and rivers as part of ecological studies in the U.S. Geological Survey's National Water-Quality Assessment (NAWQA) Program. Information from these ecologic al studies, together with chemical and physical data, provide an integrated assessment of water quality at local, regional, and nationa scales. During the program's first decade of operation (1991 - 2001), ecological studies were communities in about 59 study units (Gilliom and others, 1995). In the second decade of the

nom $2001-20111$ hi

\begin{tabular}{|c|c|c|c|}
\hline Subspecies & Taxon & CommonName & ITISTSN \\
\hline NULL & Ameiurus brunneus & snail bullhead & 164035 \\
\hline NULL & Ameiurus melas & black bullhead & 164039 \\
\hline NULL & Ameiurus natalis & yellow bullhead & 164041 \\
\hline NULL & Ameiurus nebulosus & brown bullhead & 164043 \\
\hline NULL & Ameiurus platycephalus & flat bullhead & 164045 \\
\hline NULL & Amia calva & bowfin & 161104 \\
\hline NULL & Aphredoderus sayanus & pirate perch & 164405 \\
\hline NULL & Campostoma oligolepis & largescale stoneroller & 163509 \\
\hline NULL & Campostoma pauciradii & bluefin stoneroller & 163511 \\
\hline NULL & Carassious auratus & goldfish & 163350 \\
\hline NULL & Catostomus commersoni & white sucker & 553273 \\
\hline
\end{tabular}

finesque, 1820 - bullheads
bulosus (Lesueur, 1819 ) -- barbotle brune, brown bullhead

\begin{tabular}{|l|l|l|l|}
\hline Genus & Species & Subspecies & Taxon \\
\hline Ameiurus & Ameiurus brunneus & NULL & Ameiurus b \\
\hline Ameiurus & Ameiurus melas & NULL & Ameiurus m \\
\hline Ameiurus & Ameiurus natalis & NULL & Ameiurus n \\
\hline Ameiurus & Ameiurus nebulosus & NULL & Ameiurus n \\
\hline Ameiurus & Ameiurus platycephalus & NULL & Ameiurus p \\
\hline Amia & Amia calva & NULL & Amia calva \\
\hline Aphredoderus & Aphredoderus sayanus & NULL & Aphredoder \\
\hline Campostoma & Campostoma oligolepis & NULL & Campostom \\
\hline Campostoma & Campostoma pauciradii & NULL & Campostom \\
\hline Carassious & Carassious auratus & NULL & Carassious \\
\hline Catostomus & Catostomus commersoni & NULL & Catostomus \\
\hline rus Rafinesque, 1820 - bullneads
\end{tabular}

(n)

\section{Daily Stream Discharge Information}

\section{ZUSES}

USGS National Water Quality Assessment Data Warehouse 


\section{Site and Chemical Constituent Information}

The "Site Information" option on the data warehouse home page provides details about NAWQA sampling sites. In addition to site information, several types of maps are available, including topographic maps (fig. 8).

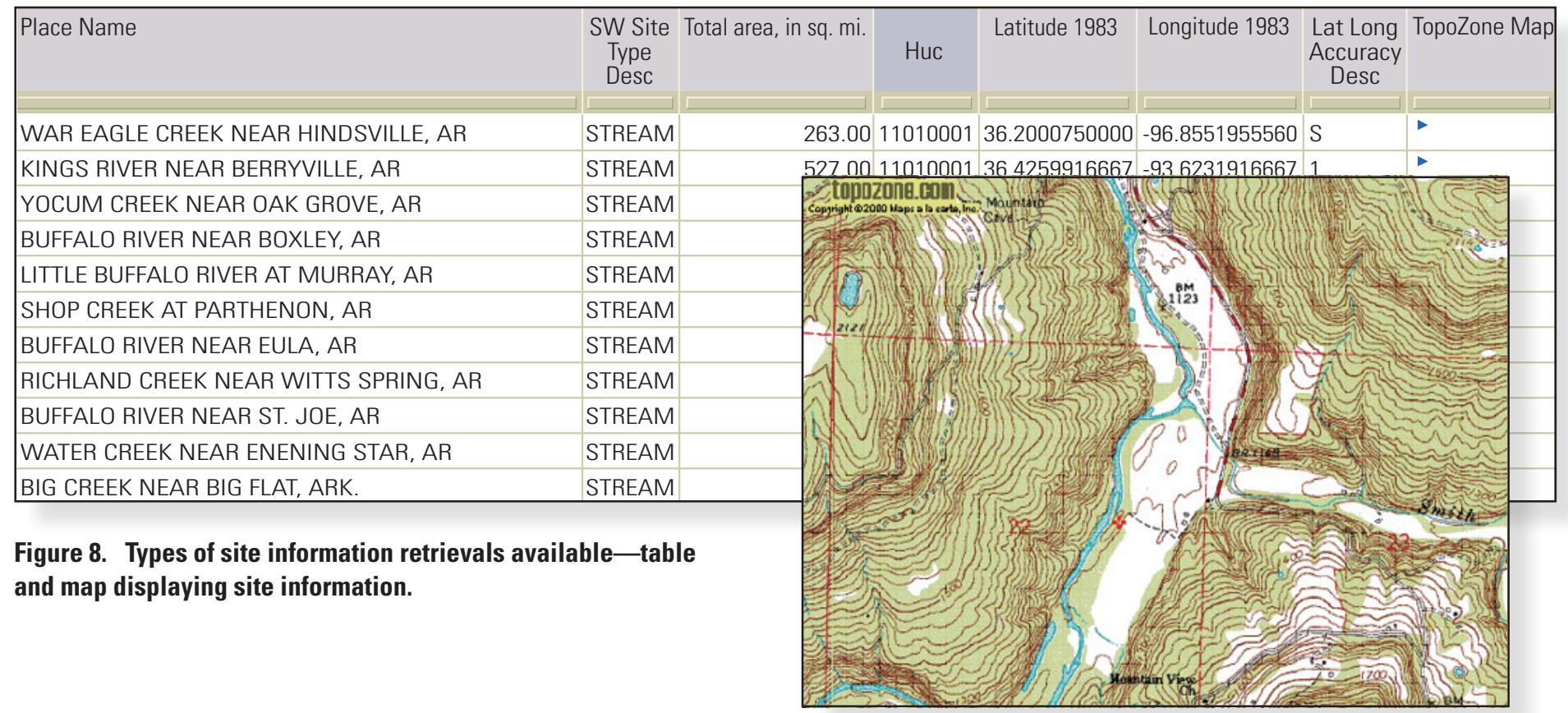

The "Constituent Finder" option on the data warehouse home page allows users to obtain information about specific chemicals that the NAWQA Program has investigated. For example, the Constituent Finder can be used to retrieve information about atrazine (fig. 9).

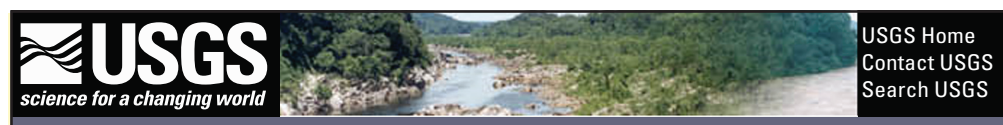

USGS National Water Quality Assessment Data Warehouse

NAWQA Data Home

MAP SITES \&

RESULTS

Map Chemical Conc.

RETRIEVE DATA

Site Information

Constituent Finder

Ground Water

Surface Water/ Bed

Sediment

Mixed (SW \& GW)

Animal Tissue

Daily Stream Discharge

Bio Community

SEARCH SUMMARY

REPORTS

HELP

Data Retrieval Tips

About NAWQA Data

Glossary

FAQ

Contact Us

Other USGS Data

What's New

NAWQA Program

Home

\section{Constituent Finder Application}

Search by Parameter Name:

(i.e. phos) $(\%=$ wildcard)

$\%$ Atrazine

AND/OR

Select a Sampling Schedule:

Search All Schedules

AND/OR

Limit parameters returned to only those that are $\mathrm{s}$

than $\mathrm{X}$ percent of the time. Enter Percent:

0

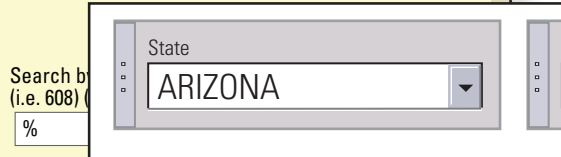

Parameter Code Name

39632 ATRAZINE, WATER, DISSOLVED, RE

Figure 9. Chemical constituent information. 


\title{
Online Help
}

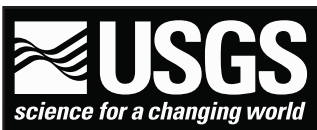

Users can access several types of online help to assist in creating retrievals and formatting output (fig. 10).

\section{USGS National Water Quality Assessment Data Warehouse}

\section{NAWQA Data Home \\ MAP SITES \& \\ Retrieval Tips}

RESULTS

Map Chemical Conc.

Water Quality: Data Retrieval Tips

Biological Community: Data Retrieval Tips

RETRIEVE DATA

Site Information

Constituent Finder

Ground Water

Question: How do I locate water-quality data for surface-water sites near my home?

Answer: Select the "Surface Water/Bed Sediment" link under "Retrieve Data"

\begin{abstract}
Select an output format from the "Choose a Surface Water Query Output below" drop-down menu, then press "Go"

Select the desired State and County options

Select the desired lab schedule(s) OR parameters

Select additional search criteria as needed Select "Go" at the bottom of the page
\end{abstract}

\section{Using Search Criteria}

Search criteria are used to specify what data should be retrieved. Most retrievals allow you to specify search criteria for several variables (e.g. NAWQA Study Unit, State, and County). In most cases you are asked to select the criteria from drop-down lists (e.g. State). In a few cases you are asked to input a value directly (e.g. Huc).

\section{Helpful Hints}

- Use Sample Medium to specify the type(s) of samples that you are interested in. This criterion is not available for the fish community queries. But it is available for the Sample Count, invertebrate, and algae queries

- If you run a retrieval and then decide to run it again, the second retrieval will use the same search criteria unless you edit them. For example, if you retrieve data by state and then want to retrieve data by study unit you'll need to clear the state selection first.

Figure 10. Examples of online help options.

\section{Miscellaneous hints}

formation can be expanded; adjust the window as needed.

efresh" button on the browser menu bar (and/or open up a new browser session), mething overwhelmed the system in your data request. Enter password - JQPUBLIC

ify must be true for data to be retrieved. For example, if you specify the following y: state $=\{$ Colorado or Nebraska $\}$ and NAWOA study Unit $=\{$ South Platte $\}$, then you sites in Colorado or Nebraska that are part of the South Platte Study. To make the ave Study Unit set to 'Do Not Search by Study Unit'.

ms that are false, the results of the query will be "This worksheet doesn't contain lowa $\}$ and NAWQA study unit=\{Southern Florida\}). Similarly, if both the "Enter or "Enter or Select Parameter Name" search criteria are used, then results of the query will be "This worksheet doesn't contain any data". Be sure that either "Do not search by lab schedule" or "Do not search by parameter name" is selected from the appropriate search criterion. Occasionally, after multiple queries have been performed using the same browser window, a data retrieval will result in the message "This worksheet doesn't contain any data". The "fix" for this situation is re-run the query after having closed all browser windows (and then opening a new browser window and re-attaching to the data warehouse.)

\section{Additional Information about the NAWOA Data Warehouse and NAWOA Program}

Information about the data warehouse and direct access to the data described in this fact sheet are available at:

http://water.usgs.gov/nawqa/data

Information about the NAWQA Program is available at: http://water.usgs.gov/nawqa

Contacts for the NAWQA Data Warehouse:

Sandy (Alex) K. Williamson, akwill@usgs.gov, Database Team Leader, Tacoma, WA

Nate Booth, nlbooth@usgs.gov, Database Developer, Madison, WI

Rick Bell, rwbell@usgs.gov, Database Testing and Support, Albuquerque, NM

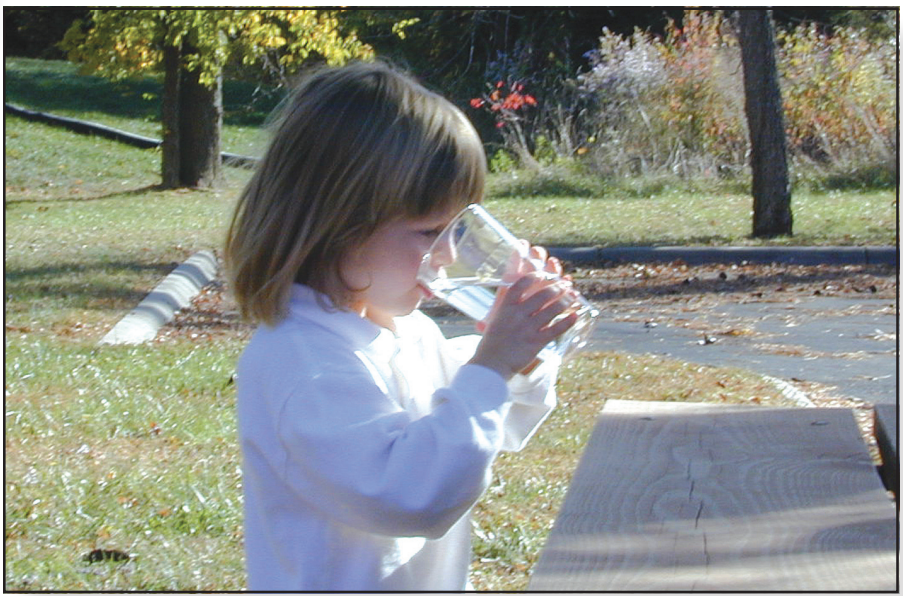

